\title{
Trends in cardiovascular disease risk factors in children and adolescents: Tehran Lipid and Glucose Study
}

S. Moradi and F. Azizi ${ }^{2}$

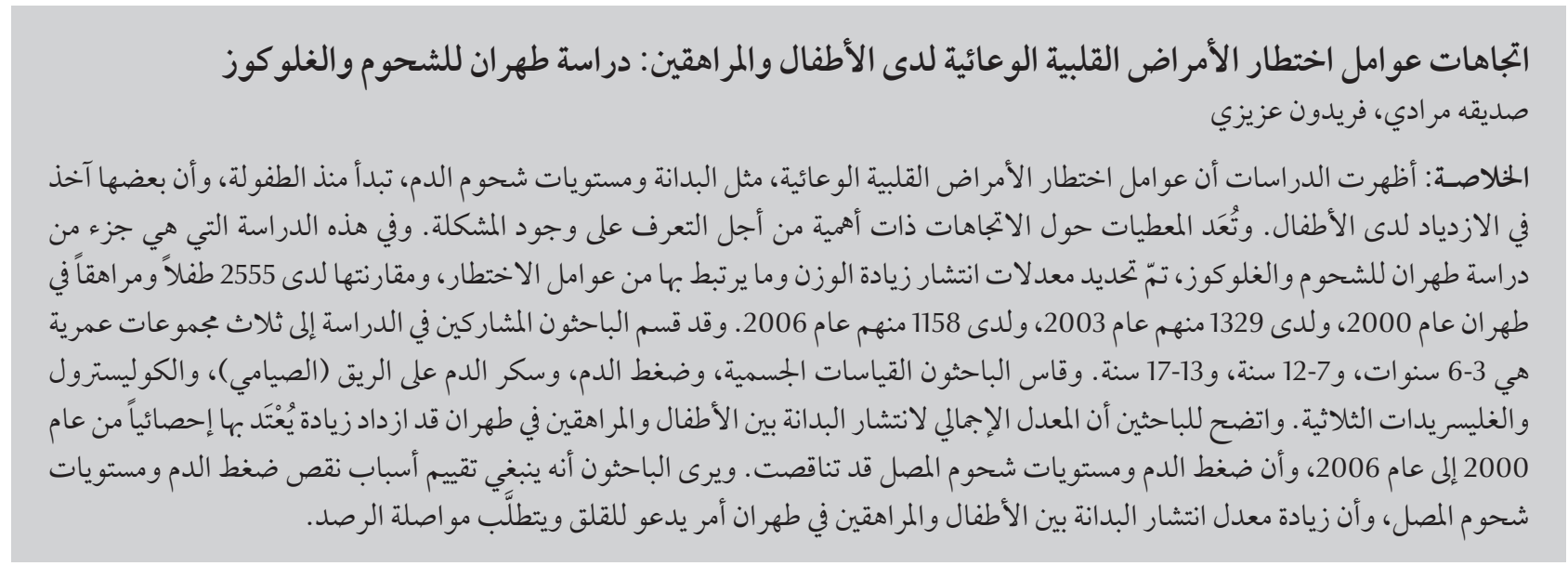

ABSTRACT Studies have shown that cardiovascular risk factors, such as obesity, blood lipid levels, start early in childhood and some are on the rise in children. Data on trends are important in order to identify if there is a problem. This study, part of the Tehran Lipid and Glucose Study, determined and compared the prevalence of overweight and its associated risk factors in 2555, 1329 and 1158 Tehran children and adolescents in 2000, 2003 and 2006 respectively. The participants were categorized into age groups 3-6, 7-12 and 13-17 years. Body mass index measurements were taken and blood pressure, fasting blood glucose, cholesterol and triglycerides measured. Overall the prevalence of obesity in Tehran children and adolescents increased significantly from 2000 to 2006 while blood pressure and serum lipid concentrations decreased. The causes for the decreased blood pressure and serum lipid concentrations should be evaluated. The increased prevalence of obesity in Tehran children and adolescents is of concern and requires monitoring.

Tendances des facteurs de risque des maladies cardiovasculaires chez l'enfant et l'adolescent : étude sur le glucose et les lipides réalisée à Téhéran

RÉSUMÉ Des études ont démontré que les facteurs de risque cardiovasculaires tels que l'obésité et une hyperlipidémie s'installaient de manière précoce dans l'enfance et certains étaient en augmentation chezl'enfant. Des données sur les tendances sont importantes afin de repérer l'émergence d'un problème. Le présent essai fait partie de l'étude sur le glucose et les lipides réalisée à Téhéran. Il vise à déterminer et comparer la prévalence du surpoids et des facteurs de risque associés chez 2 555, 1329 et 1158 enfants et adolescents de Téhéran en 2000, 2003 et 2006 respectivement. Les participants ont été répartis par tranches d'âge de 3 à 6 ans, de 7 à 12 ans et de 13 à 17 ans. Des évaluations de l'indice de masse corporelle ont été réalisées et la pression artérielle, la glycémie à jeun, le taux de cholestérol et des triglycérides ont été mesurés. Globalement, la prévalence de l'obésité chez l'enfant et l'adolescent à Téhéran a nettement augmenté entre 2000 et 2006 alors que la tension artérielle et les concentrations sériques de lipides ont diminué. Les causes de la diminution de la pression artérielle et des concentrations sériques de lipides doivent être évaluées. La prévalence accrue de l'obésité chez l'enfant et de l'adolescent à Téhéran est préoccupante et appelle une surveillance.

'Endocrine Research Center (Firouzgar), Institute of Endocrinology and Metabolism, Tehran University of Medical Sciences Tehran, Islamic Republic of Iran (Correspondence to S.Moradi: s-moradi@tums.ac.ir).

${ }^{2}$ Research Institute for Endocrine Sciences, Shahid Beheshti University of Medical Sciences, Tehran, Islamic Republic of Iran.

Received: 15/03/12; accepted: 19/06/12 


\section{Introduction}

The increasing prevalence of obesity in recent years is a serious concern worldwide, in both developed and developing countries [1]. It is estimated that over 22 million children worldwide under the age of 5 years are overweight [2]. Occurring simultaneously with increasing numbers of overweight and obese children is an increase in the prevalence of metabolic syndrome, which consists of a set of risk factors for cardiovascular disease [3]. In a study involving obese children, the prevalence of metabolic syndrome was 35\% in the obese group and $44 \%$ in the severely obese group [4].

In developed countries, the increase in cardiovascular risk factors is inversely related to socioeconomic status; however, in developing countries, where changes are occurring in welfare and nutritional status, this is reversed $[5,6]$. A study, conducted in America using national surveys from 1963 to 2002 in children 8-17 years old, found that high blood pressure and pre-high blood pressure in children and adolescents were on the rise [7]. In addition to general obesity, as described by body mass index (BMI), the increase in abdominal fat, based on waist circumference, is a better index for metabolic disorders and cardiovascular risk factors in all ages [8].

During the period 1993-1999 in the Islamic Republic of Iran, the obesity prevalence in children and adolescents doubled [9]. In a study performed in a group of females 14-17 years old, overweight and obesity rates were $21.9 \%$ and 5.3\%, respectively [10]. In a study involving children 7-12 years old, more than $12 \%$ showed waist circumferences above the $90^{\text {th }}$ percentile [11]. Another study conducted in children between 10-19 years old in Tehran city reported a metabolic syndrome prevalence of $10.1 \%[12]$.

The Islamic Republic of Iran experienced a nutrition transition in the past decade and there was a lack of information on changes in cardiovascular risk factors in children and adolescents over this period of time in our capital city (Tehran). Therefore the aim of this study was to compare cardiovascular risk factors in children and adolescents in 2000, 2003 and 2006 in Tehran.

\section{Methods}

This study was conducted as a part of the Tehran Lipid and Glucose Study, and the details have been published previously [13]. This consisted of was 3 cross-sectional studies over 3 time periods: 2000, 2003 and 2006 in which $2555,1329,1158$ children and adolescents (3-17 years old) participated respectively. Briefly, the children and adolescents recruited were residents of district No. 13 of Tehran (one of the 22 districts of the city) and were under the coverage of three medical health centres. A total of 15005 individuals aged 3 years and over were selected using multistage cluster random sampling method. All members of each family, including those not having risk factors, were invited for baseline measurements to be followed every 3 years. The age distribution and socioeconomic status of the population in district No. 13 is representative of overall population of Tehran.

In each phase of the study, a questionnaire was completed, which included past medical record, family history of noncommunicable diseases, amount of physical activity and cigarette smoking. A short physical examination was performed which included height and weight measurements to calculate body mass index (BMI), waist circumference and blood pressure measurements. Weight was measured without shoes and with just underwear. Height measurements were performed using a standard method [13]. Waist circumference was measured about the naval, and the hip circumference was also recorded at the highest point of the hip with a meter measuring tape. BMI was calculated by dividing the weight $(\mathrm{kg})$ by height squared $\left(\mathrm{m}^{2}\right)$. Blood pressure was recorded in a sitting position after 15 minutes of rest in two 5-minute intervals. These measurements were done with a standard mercury sphygmomanometer on the right arm, and the mean of the two-recorded measurements was used for comparison.

A venous blood sample was taken from each subject in a sitting position between 07:00 and 09:00 following 12-14 hours of fasting. Total cholesterol and triglyceride levels were measured by an enzymatic method and chromatography (Kit Pars Test, Islamic Republic of Iran) was measured after lipoprotein precipitations containing apolipoprotein-B. LDL was calculated with the Friedewald formula [14]. Glucose was measured by an enzymatic assay and with chromatography by a glucose oxidase method. Inter- and intra-assay coefficients of variation were $2.2 \%$ for glucose, $2 \%$ and $0.5 \%$ for total cholesterol and $1.6 \%$ and $0.6 \%$ for triglycerides, respectively.

The methods for clinical and laboratories measurements were the same in the 3 phases of the study.

\section{Definitions}

Overweight and obesity were defined according to the international percentile in each sex for 2-18 years [15]. Cholesterol concentrations of $\geq 200$ $\mathrm{mg} / \mathrm{dL}$ were considered high and those of $170-200 \mathrm{mg} / \mathrm{dL}$ were considered borderline high. LDL concentrations $>130 \mathrm{mg} / \mathrm{dL}$ were considered high and those $110-130 \mathrm{mg} / \mathrm{dL}$ considered borderline high. Triglyceride levels > $150 \mathrm{mg} / \mathrm{dL}$ and HDL levels < $35 \mathrm{mg} /$ dL were considered abnormal [16].

\section{Statistical analyses}

Subjects were divided into three age groups (3-6, 7-12, and 13-17 years old) in each of the 3 study phases. The mean and standard deviation of 
each variable were calculated for each temporal period for all participants and in each age group for both sexes. ANOVA was used to compare the variable means in the defined time periods and between different age groups and sexes. If the ANOVA test was significant, a multiple comparison test was used to evaluate the groups. $P<0.05$ was considered statistically significant.

\section{Results}

In 2000, 2003, and 2006, 2 555, 1329 , 1158 children participated in the study respectively. Their mean ages and the number of subjects in each age group are shown in Table 1.

Changes in cardiovascular risk factors for girls and boys are shown in Tables 2 and 3 respectively. BMI significantly increased from 2000 to 2006 in both genders in the 13-17 years age group. Waist circumference increased significantly in all age groups for boys in 2006, compared with 2000. Blood pressure decreased significantly in all age groups of girls from 2000-2006.

Table 4 shows the data on the abnormality in risk factors in the 3 intervals in the study. The overweight prevalence in boys in the 13-17 years age group was greater compared to the other groups in all 3 periods.

An abnormal waist circumference was defined as being greater than the $70 \%$ percentile for that gender and age. The boys in all age groups showed increased waist circumferences in the second and third periods; however, no increases were observed in the girls in any age group.

In 2000, total cholesterol values were high in $41 \%$ of the boys. Of these, $27 \%$ had cholesterol values between 170 and $200 \mathrm{mg} / \mathrm{dL}$, and $14 \%$ had cholesterol values $>200 \mathrm{mg}(P=0.0001)$. In 2003, 27\% of the boys had increased cholesterol levels, 20\% of whom had values between 170 and $200 \mathrm{mg} / \mathrm{dL}$ and $7 \%$ had values $>200 \mathrm{mg}(P=0.01)$. In 2006, 23.8\% of the boys had increased cholesterol levels, of whom $17.8 \%$ had values between 170 and $200 \mathrm{mg} / \mathrm{dL}$ and $6.0 \%$ had values $>200 \mathrm{mg}(P=0.01)$

In $2000,48.7 \%$ of the girls had high cholesterol levels, of whom $17.8 \%$ had levels between 170 and $200 \mathrm{mg} / \mathrm{dL}$ and 29.9\% had levels > $200 \mathrm{mg}$. In 2003, $32.7 \%$ of the girls had high cholesterol levels, of whom $23.6 \%$ had levels between 170 and $200 \mathrm{mg} / \mathrm{dL}$ and $9.1 \%$ had levels $>200 \mathrm{mg}(P=0.0001)$. In 2006, 32.4\% of the girls had increased cholesterol levels, $23.6 \%$ of whom had

\begin{tabular}{|c|c|c|}
\hline \multirow[t]{2}{*}{ Age group (years) } & No. & Mean age (SD) (years) \\
\hline & \multicolumn{2}{|c|}{2000} \\
\hline $3-6$ & 430 & $4.8(1.0)$ \\
\hline $7-12$ & 1030 & $9.8(1.7)$ \\
\hline \multirow[t]{2}{*}{$13-17$} & 1095 & $15(1.4)$ \\
\hline & \multicolumn{2}{|c|}{2003} \\
\hline $3-6$ & 204 & $5(0.9)$ \\
\hline $7-12$ & 485 & $9.7(1.7)$ \\
\hline \multirow[t]{2}{*}{$13-17$} & 640 & $15(1.4)$ \\
\hline & \multicolumn{2}{|c|}{2006} \\
\hline $3-6$ & 172 & $5(1.0)$ \\
\hline $7-12$ & 456 & $9.5(1.7)$ \\
\hline 13-17 & 530 & $15(1.4)$ \\
\hline
\end{tabular}

$S D=$ standard deviation .

levels between 170 and $200 \mathrm{mg} / \mathrm{dL}$ and $8.8 \%$ had levels $>200 \mathrm{mg} / \mathrm{dL}(P=0.01)$.

The high triglyceride levels in both boys and girls decreased significantly during the 3 periods. In 2000, LDL levels were high in $37.2 \%$ of the boys in all age groups, of whom $23.4 \%$ had levels between $110 \mathrm{mg} / \mathrm{dL}$ and $129 \mathrm{mg} / \mathrm{dL}$ and $13.8 \%$ had levels $>130 \mathrm{mg} / \mathrm{dL}$. In 2003, LDL levels in $21 \%$ of the boys were between $110 \mathrm{mg} / \mathrm{dL}$ and $129 \mathrm{mg} /$ $\mathrm{dL}$ and in $13.8 \%$ they were higher than $130 \mathrm{mg} / \mathrm{dL}(P=0.04)$. In 2006, LDL levels were high in $26.3 \%$ of boys, of whom $15.4 \%$ had levels between 110 $\mathrm{mg} / \mathrm{dL}$ and $129 \mathrm{mg} / \mathrm{dL}$ and $10.9 \%$ had levels $>130(P=0.006)$. In 2000, LDL in $24 \%$ of the total number of girls was between $110 \mathrm{mg} / \mathrm{dL}$ and $129 \mathrm{mg} / \mathrm{dL}$ and in $17.4 \%$ it was $>130 \mathrm{mg} / \mathrm{dL}$. In 2003, LDL in $21.6 \%$ of the girls was between $110 \mathrm{mg} / \mathrm{dL}$ and $129 \mathrm{mg} / \mathrm{dL}$ and in $14.7 \%$ was $>130 \mathrm{mg} / \mathrm{dL}(P=$ $0.01)$; In 2006 these figures were $13.2 \%$ and $9.0 \%$ respectively $(P=0.001)$.

\section{Discussion}

This study showed that indices of general and abdominal obesity increased but blood pressure and lipidaemia decreased in children and adolescents in Tehran, Islamic Republic of Iran, which is undergoing a nutrition transition. This study is the first epidemiological survey the country to compare the cardiovascular risk factors among children in 6-year intervals. The findings are important because Iran has undergone some rapid changes in recent years in the following categories: nutritional status and physical activities in children and adolescents, reproduction and mortality rates, and urbanization status. Overweight and obesity can help predict cardiovascular disease development in the future. Additionally, high waist circumference (as an index of abdominal obesity) and decreased HDL increase the risk of noncommunicable diseases in adulthood, which can be triggered at a lower age. 


\begin{tabular}{|c|c|c|c|c|c|c|c|c|c|}
\hline \multirow[t]{2}{*}{ Variable } & \multicolumn{2}{|r|}{2000} & \multicolumn{2}{|r|}{2003} & \multirow[t]{2}{*}{$p^{a}$} & \multicolumn{2}{|r|}{2006} & \multirow[t]{2}{*}{$p b$} & \multirow[t]{2}{*}{$p^{c}$} \\
\hline & No. & Mean (SD) & No. & Mean (SD) & & No. & Mean (SD) & & \\
\hline \multicolumn{10}{|c|}{ Age group 3-6 years } \\
\hline $\mathrm{SBP}(\mathrm{mm} / \mathrm{Hg})$ & 205 & $97.3(0.8)$ & 95 & $87.6(1.1)$ & 0.0001 & 68 & $88.3(1.4)$ & 0.9 & 0.0001 \\
\hline $\mathrm{DBP}(\mathrm{mm} / \mathrm{Hg})$ & 204 & $66.8(0.7)$ & 95 & $56.8(1.1)$ & 0.0001 & 68 & $58.7(1.1)$ & 0.9 & 0.0001 \\
\hline $\mathrm{BMI}\left(\mathrm{kg} / \mathrm{m}^{2}\right)$ & 213 & $15(0.1)$ & 93 & $15.3(1.7)$ & 0.5 & 66 & $15.6(0.2)$ & 0.9 & 0.1 \\
\hline WC (cm) & 132 & $51.4(0.4)$ & 61 & $0.87(0.6)$ & 0.9 & 46 & $51.4(0.6)$ & 0.9 & 0.9 \\
\hline $\mathrm{WC} / \mathrm{HC}$ ratio & 132 & $0.86(0.004)$ & 61 & $0.87(0.006)$ & 0.4 & 46 & $0.86(0.007)$ & 0.4 & 0.9 \\
\hline $\mathrm{FBS}(\mathrm{mg} / \mathrm{dL})$ & 175 & $82(0.6)$ & 83 & $83(0.8)$ & 0.9 & 66 & $80.5(0.9)$ & 0.2 & 0.8 \\
\hline Total chol (mg/dL) & 175 & $173(2)$ & 83 & $165(3.3)$ & 0.1 & 66 & $167(3.6)$ & 0.9 & 0.5 \\
\hline Triglycerides (mg/dL) & 175 & $89(2.7)$ & 83 & $83.5(3.7)$ & 0.6 & 66 & $78.8(3.4)$ & 0.9 & 0.1 \\
\hline HDL-chol (mg/dL) & 169 & $44.4(0.7)$ & 81 & $41.4(1)$ & 0.09 & 63 & $46.4(1.4)$ & 0.01 & 0.5 \\
\hline LDL-chol (mg/dL) & 169 & $111(1.9)$ & 83 & $108(3)$ & 0.9 & 60 & $105(3.5)$ & 0.9 & 0.4 \\
\hline \multicolumn{10}{|c|}{ Age group 7-12 years } \\
\hline $\mathrm{SBP}(\mathrm{mm} / \mathrm{Hg})$ & 507 & $101(0.4)$ & 249 & $95(0.5)$ & 0.0001 & 223 & $92.7(0.7)$ & 0.03 & 0.0001 \\
\hline $\mathrm{DBP}(\mathrm{mm} / \mathrm{Hg})$ & 507 & $7(0.4)$ & 249 & $64.4(0.5)$ & 0.0001 & 223 & $60.8(0.6)$ & 0.0001 & 0.0001 \\
\hline $\operatorname{BMI}\left(\mathrm{kg} / \mathrm{m}^{2}\right)$ & 509 & $17(0.001)$ & 243 & $17.5(0.2)$ & 0.2 & 224 & $18(0.2)$ & 0.2 & 0.001 \\
\hline WC (cm) & 509 & $60.4(0.4)$ & 242 & $61(0.6)$ & 0.9 & 224 & $61.2(0.6)$ & 0.9 & 0.9 \\
\hline $\mathrm{WC} / \mathrm{HC}$ ratio & 509 & $0.82(0.002)$ & 242 & $0.82(0.003)$ & 0.9 & 224 & $0.80(0.003)$ & 0.001 & 0.001 \\
\hline $\mathrm{FBS}(\mathrm{mg} / \mathrm{dL})$ & 500 & $87(0.3)$ & 244 & $88.4(0.4)$ & 0.06 & 231 & $86.8(0.4)$ & 0.1 & 0.9 \\
\hline Total chol (mg/dL) & 500 & $176(1.5)$ & 244 & $166(1.9)$ & 0.001 & 231 & $163(2)$ & 0.5 & 0.0001 \\
\hline Triglycerides (mg/dL) & 500 & $105(2.2)$ & 244 & $106(3.4)$ & 0.9 & 231 & $98.2(3)$ & 0.2 & 0.1 \\
\hline HD-chol (mg/dL) & 499 & $45(0.5)$ & 243 & $42(0.6)$ & 0.001 & 230 & $45.5(0.7)$ & 0.001 & 0.9 \\
\hline LDL-chol (mg/dL) & 499 & $109(1.4)$ & 243 & $103(1.7)$ & 0.02 & 218 & $96.2(1.7)$ & 0.02 & 0.02 \\
\hline \multicolumn{10}{|c|}{ Age group $13-17$ years } \\
\hline $\mathrm{SBP}(\mathrm{mm} / \mathrm{Hg})$ & 570 & $105(0.4)$ & 329 & $101(0.6)$ & 0.001 & 250 & $100(0.6)$ & 0.8 & 0.0001 \\
\hline $\mathrm{DBP}(\mathrm{mm} / \mathrm{Hg})$ & 570 & $72(0.3)$ & 329 & $69(0.5)$ & 0.001 & 250 & $66.3(0.5)$ & 0.001 & 0.0001 \\
\hline $\mathrm{BMI}\left(\mathrm{kg} / \mathrm{m}^{2}\right)$ & 569 & $21(0.1)$ & 317 & $21.6(0.2)$ & 0.006 & 245 & $22.1(0.2)$ & 0.4 & 0.006 \\
\hline WC (cm) & 569 & $71(0.3)$ & 317 & $72.5(0.5)$ & 0.9 & 245 & $70.8(0.5)$ & 0.07 & 0.9 \\
\hline WC/HC ratio & 569 & $0.76(0.002)$ & 317 & $0.78(0.003)$ & 0.001 & 245 & $0.75(0.003)$ & 0.0001 & 0.1 \\
\hline FBS (mg/dL) & 573 & $87.7(0.3)$ & 324 & $87.9(0.4)$ & 0.004 & 254 & $85.7(0.4)$ & 0.003 & 0.004 \\
\hline Total chol (mg/dL) & 573 & $170(1.2)$ & 324 & $153(1.4)$ & 0.001 & 254 & $154(1.7)$ & 0.9 & 0.3 \\
\hline Triglycerides (mg/dL) & 573 & $113(2.5)$ & 324 & $102(2.6)$ & 0.03 & 254 & $103(3.4)$ & 0.9 & 0.3 \\
\hline HDL-chol (mg/dL) & 573 & $42.9(0.4)$ & 324 & $39.4(0.4)$ & 1 & 253 & $43(0.6)$ & 0.0001 & 0.9 \\
\hline LDL-chol (mg/dL) & 571 & $154(1)$ & 324 & $93.7(1.3)$ & 0.001 & 243 & $90.4(1.5)$ & 0.3 & 0.0001 \\
\hline
\end{tabular}

${ }^{a}$ Comparison between 2000 and 2003; ${ }^{b}$ Comparison between 2003 and 2006; ${ }^{c}$ Comparison between 2000 and 2006.

$S P B=$ systolic blood pressure; $D B P=$ diastolic blood pressure; $B M I=$ body mass index; $W C=$ waist circumference; $H C=$ hip circumference; $F B S=$ fasting blood sugar; Chol = cholesterol; $H D L$-chol = high-density lipoprotein cholesterol; $L D L$-chol =low-density lipoprotein cholesterol.

Although unexpected, favourable changes in blood pressure and serum lipid concentrations were observed in this study, despite increases in general and abdominal obesity. These results are probably due to the national programme that is designed to decrease salt and lipid consumption. This programme consists of consumption of more unsaturated fat and replacement of lipid oil for solid oil and educating the public on proper nutrition, exercise and diet through the media. None of these subjects were receiving anti-hypertensive or anti-lipid drug treatments.

The high prevalence of low HDL is probably due to specific genetic backgrounds as it has been previously reported in Iranian adults [12]. High prevalence of low HDL has also been reported in other Middle Eastern countries, such as Turkey and Oman $[17,18]$. Along with genetic background, what is eaten in childhood, such as diets with high levels of solid hydrogenated oils that contain transacids and/or saturated fats, can also cause HDL cholesterol and triglyceride increases [19].

An NHANES study found that the overweight prevalence increased from 


\begin{tabular}{|c|c|c|c|c|c|c|c|c|c|}
\hline \multirow[t]{2}{*}{ Variable } & \multicolumn{2}{|r|}{2000} & \multicolumn{2}{|r|}{2003} & \multirow[t]{2}{*}{$P^{a}$} & \multicolumn{2}{|r|}{2006} & \multirow[t]{2}{*}{$P^{\mathrm{b}}$} & \multirow[t]{2}{*}{$\boldsymbol{P}^{\mathrm{c}}$} \\
\hline & No. & Mean (SD) & No. & & & No. & Mean (SD) & & \\
\hline \multicolumn{10}{|c|}{ Age group 3-6 years } \\
\hline $\mathrm{SBP}(\mathrm{mm} / \mathrm{Hg})$ & 380 & $98.7(0.5)$ & 196 & $88.6(0.7)$ & 0.001 & 162 & $89.1(0.8)$ & 0.9 & 0.0001 \\
\hline $\mathrm{DBP}(\mathrm{mm} / \mathrm{Hg})$ & 378 & $67.8(0.4)$ & 196 & $59(0.7)$ & 0.001 & 162 & $58.5(0.6)$ & 0.9 & 0.0001 \\
\hline $\mathrm{BMI}\left(\mathrm{kg} / \mathrm{m}^{2}\right)$ & 414 & $15(0.09)$ & 195 & $15.3(0.1)$ & 0.01 & 159 & $16.3(0.8)$ & 0.1 & 0.06 \\
\hline WC $(\mathrm{cm})$ & 246 & $51(0.3)$ & 117 & $52(0.4)$ & 0.03 & 112 & $52.4(0.4)$ & 0.9 & 0.001 \\
\hline $\mathrm{WC} / \mathrm{HC}$ ratio & 114 & $0.87(0.004)$ & 56 & $0.89(0.006)$ & 0.01 & 66 & $0.91(0.005)$ & 0.1 & 0.0001 \\
\hline FBS (mg/dL) & 330 & $61.8(0.5)$ & 175 & $83(0.6)$ & 0.8 & 153 & $82.4(0.6)$ & 0.9 & 0.2 \\
\hline Total chol (mg/dL) & 330 & $171(1.5)$ & 175 & $161(2.3)$ & 0.001 & 153 & $160(2.4)$ & 0.9 & 0.004 \\
\hline Triglycerides (mg/dL) & 330 & $86.5(1.9)$ & 175 & $80(2.3)$ & 0.005 & 153 & $76(2)$ & 0.8 & 0.07 \\
\hline HDL-chol (mg/dL) & 317 & $45(0.5)$ & 175 & $41(0.7)$ & 0.9 & 148 & $46(0.8)$ & 0.001 & 0.9 \\
\hline LDL-chol (mg/dL) & 317 & $107(1.4)$ & 175 & $103(2)$ & 0.004 & 142 & $99(2.2)$ & 0.3 & 0.02 \\
\hline \multicolumn{10}{|c|}{ Age group 7-12 years } \\
\hline $\mathrm{SBP}(\mathrm{mm} / \mathrm{Hg})$ & 996 & $102(0.3)$ & 474 & $96(0.5)$ & 0.001 & 437 & $93(0.5)$ & 0.001 & 0.0001 \\
\hline $\mathrm{DBP}(\mathrm{mm} / \mathrm{Hg})$ & 996 & $70(0.3)$ & 474 & $64.3(0.4)$ & 0.001 & 437 & $61(0.4)$ & 0.001 & 0.0001 \\
\hline BMI $\left(\mathrm{kg} / \mathrm{m}^{2}\right)$ & 1005 & $16.8(0.1)$ & 460 & $17.4(0.1)$ & 0.001 & 439 & $17.8(0.1)$ & 0.5 & 0.2 \\
\hline WC $(\mathrm{cm})$ & 1005 & $59(0.2)$ & 459 & $61.8(0.4)$ & 0.001 & 439 & $62.4(0.5)$ & 0.9 & 0.0001 \\
\hline $\mathrm{WC} / \mathrm{HC}$ ratio & 496 & $0.84(0.002)$ & 217 & $0.89(0.02)$ & 0.001 & 215 & $0.88(0.006)$ & 0.9 & 0.003 \\
\hline FBS (mg/dL) & 980 & $87.5(0.2)$ & 466 & $89(0.3)$ & 0.9 & 440 & $87(0.3)$ & 0.001 & 0.9 \\
\hline Total chol (mg/dL) & 980 & $174(1)$ & 466 & $164(1.3)$ & 0.001 & 440 & $161(1.3)$ & 0.4 & 0.0001 \\
\hline Triglycerides (mg/dL) & 978 & $100(1.5)$ & 466 & $100(2.4)$ & 0.004 & 440 & $91(1.9)$ & 0.01 & 0.01 \\
\hline HDL-chol (mg/dL) & 972 & $46.5(0.3)$ & 465 & $42.5(0.4)$ & 0.9 & 439 & $46.8(0.5)$ & 0.001 & 0.0001 \\
\hline LDL-chol (mg/dL) & 969 & $107(0.9)$ & 463 & $101(1)$ & 0.004 & 420 & $95(1)$ & 0.004 & 0.0001 \\
\hline \multicolumn{10}{|c|}{ Age group $13-17$ years } \\
\hline $\mathrm{SBP}(\mathrm{mm} / \mathrm{Hg})$ & 1069 & $106(0.3)$ & 631 & $103(0.4)$ & 0.001 & 509 & $102.7(0.5)$ & 0.9 & 0.02 \\
\hline $\mathrm{DBP}(\mathrm{mm} / \mathrm{Hg})$ & 1069 & $71.9(0.2)$ & 631 & $68.4(0.3)$ & 0.001 & 509 & $66.7(0.3)$ & 0.005 & 0.0001 \\
\hline BMI $\left(\mathrm{kg} / \mathrm{m}^{2}\right)$ & 1073 & $21(0.1)$ & 616 & $21.4(0.1)$ & 0.001 & 513 & $22(0.2)$ & 0.02 & 0.0001 \\
\hline WC $(\mathrm{cm})$ & 1073 & $71(0.3)$ & 616 & $74.4(0.4)$ & 0.001 & 513 & $75(0.5)$ & 0.7 & 0.0001 \\
\hline WC/HC ratio & 504 & $0.82(0.003)$ & 299 & $0.85(0.003)$ & 0.001 & 268 & $0.86(0.004)$ & 0.04 & 0.0001 \\
\hline $\mathrm{FBS}(\mathrm{mg} / \mathrm{dL})$ & 1061 & $90(0.3)$ & 618 & $89.6(0.5)$ & 0.005 & 519 & $87(0.3)$ & 0.001 & 0.1 \\
\hline Total chol (mg/dL) & 1061 & $167(1)$ & 618 & $152(1)$ & 0.001 & 519 & $151(1.2)$ & 0.9 & 0.0001 \\
\hline Triglycerides (mg/dL) & 1061 & $114(2)$ & 618 & $105(2))$ & 0.005 & 519 & $103(2.4)$ & 0.9 & 0.1 \\
\hline HDL-chol (mg/dL) & 1056 & $42.5(0.3)$ & 618 & $38.6(0.3$ & 0.6 & 517 & $41.8(0.4)$ & 0.001 & 0.2 \\
\hline LDL-chol (mg/dL) & 1048 & $101(0.8)$ & 616 & $93(1)$ & 0.001 & 490 & $88(1)$ & 0.01 & 0.0001 \\
\hline
\end{tabular}

${ }^{a}$ Comparison between 2000 and 2003; ${ }^{b}$ Comparison between 2003 and 2006; ${ }^{c}$ Comparison between 2000 and 2006. $S D=$ standard deviation.

$S P B=$ systolic blood pressure; $D B P=$ diastolic blood pressure; $B M I=$ body mass index; $W C=$ waist circumference; $H C=$ hip circumference; $F B S=$ fasting blood sugar; Chol = cholesterol; $H D L$-chol = high-density lipoprotein cholesterol; $L D L$-chol=low-density lipoprotein cholesterol.

$4 \%$ to $6 \%$ in $1976-1980$ and to $16 \%$ in 1999-2002 [20,21]. In this study, high blood pressure, low HDL cholesterol and triglycerides were raised in children who were overweight but there was no relationship between overweight, total cholesterol and LDL cholesterol [22].
In a study conducted in Korea in 3-year intervals for children 10-18 years old, overweight prevalence increased from $5.4 \%$ to $11.6 \%$. Triglyceride levels were significantly increased in the second period, and the LDL, HDL, and blood pressure measurements improved [23]. In our study, waist circumference and body weight significantly increased during the three defined periods. These findings are similar to a study performed in the United States in children ages 2-17 years and from the third period of NHANES to 2000. The BMI and waist circumference increased, but triglyceride and 


\begin{tabular}{|c|c|c|c|c|c|c|}
\hline \multirow[t]{2}{*}{ Variable } & 2000 & 2003 & $P$ a & 2006 & $P^{\mathrm{b}}$ & $\boldsymbol{P}^{\mathrm{c}}$ \\
\hline & No. $(\%)$ & No. (\%) & & No. (\%) & & \\
\hline \multicolumn{7}{|c|}{ Fasting blood sugar > 100 mg\% } \\
\hline Boys & $77(6.1)$ & $46(4.1)$ & 0.01 & $46(7.6)$ & 0.001 & 0.1 \\
\hline Girls & $82(3.7)$ & $36(3.30)$ & 0.1 & $31(4.8)$ & 0.1 & 0.1 \\
\hline \multicolumn{7}{|c|}{ Total cholesterol > $170 \mathrm{mg} \%$} \\
\hline Boys & $462(41.1)$ & $166(27.3)$ & 0.001 & $134(23.8)$ & 0.01 & 0.0001 \\
\hline Girls & $608(48.7)$ & $213(32.7)$ & 0.0001 & $179(32.4)$ & 0.04 & 0.01 \\
\hline \multicolumn{7}{|c|}{ LDL-chol > $110 \mathrm{mg} \%$} \\
\hline Boys & $204(37.2)$ & $560(34.8)$ & 0.04 & $482(26.3)$ & 0.006 & 0.001 \\
\hline Girls & $167(41.6)$ & $427(36.3)$ & 0.01 & $325(22.2)$ & 0.0001 & 0.0001 \\
\hline \multicolumn{7}{|c|}{ Triglyceride $>150 \mathrm{mg} \%$} \\
\hline Boys & $148(13.2)$ & $63(10.3)$ & 0.001 & $43(7.6)$ & 0.0001 & 0.0001 \\
\hline Girls & $190(15.2)$ & $80(12.2)$ & 0.07 & $62(11.2)$ & 0.006 & 0.0001 \\
\hline \multicolumn{7}{|c|}{ HDL-chol $<35$ mg\% } \\
\hline Boys & $844(76.5)$ & $370(60.9)$ & 0.001 & $446(80)$ & 0.0001 & 0.0001 \\
\hline Girls & $931(75)$ & $402(62)$ & 0.08 & $540(80.4)$ & 0.1 & 0.3 \\
\hline \multicolumn{7}{|c|}{ Overweight } \\
\hline Boys & $148(29.8)$ & $102(39.1)$ & 0.001 & 97 (43.5) & 0.1 & 0.001 \\
\hline Girls & $188(37.7)$ & $101(41.3)$ & 0.7 & $104(49.7)$ & 0.05 & 0.001 \\
\hline \multicolumn{7}{|l|}{ Obese } \\
\hline Boys & $73(15.5)$ & $38(13.2)$ & 0.6 & $54(23.3)$ & 0.001 & 0.001 \\
\hline Girls & $42(8.8)$ & $34(15.2)$ & 0.001 & $31(15)$ & 0.1 & 0.001 \\
\hline \multicolumn{7}{|c|}{ WC increase $>70 \%$ percentile } \\
\hline Boys & $149(78)$ & 135 (89) & 0.001 & $171(86)$ & 0.2 & 0.01 \\
\hline Girls & $200(49)$ & $127(64)$ & 0.001 & $91(51)$ & 0.01 & 0.1 \\
\hline
\end{tabular}

${ }^{a}$ Comparison between 2000 and 2003; ${ }^{b}$ Comparison between 2003 and 2006; ${ }^{c}$ Comparison between 2000 and 2006. $S D=$ standard deviation.

$L D L$-chol = low-density lipoprotein cholesterol; HDL-chol = high-density lipoprotein cholesterol; $W C=$ waist circumference.

glucose levels, which are associated with obesity, decreased during this time. Total cholesterol, LDL cholesterol, HDL cholesterol, and haemoglobin A1C showed no differences between the two periods [24].

It is now known that BMI does not show the body lipid percentage and is not a good prognostic factor for determining cardiovascular disease in children; therefore, waist circumference is used for estimating abdominal fat [25]. In our study, waist circumference was an important factor for developing metabolic syndrome; however, the waist-to-hip ratio was not. Our study is in accordance with previous studies that showed high waist circumference as an important characteristic in metabolic syndrome in children and adolescents [10].

There are some limitations in our study. As a cross-sectional study, the causative factors could not be evaluated and the length of the follow-up was short. Additionally, one cannot predict the future changes that may occur in this population as adults. It should also be noted that the most recent data pertain to about 6 years ago and changes in life style have continued since then which may affect the risk factors evaluated. There is a need therefore to follow up on the children and adolescents who were included in TLGS in the future.

To conclude, this study showed increasing prevalences of general and abdominal obesity in Tehran children and adolescents. These increases may cause serious public health problems in this country. The causes of blood pressure and serum lipid concentration decreases should be further evaluated.

\section{Acknowledgements}

We express appreciation to the children and adolescences and their parents in district 13, Tehran, for their support in this study. We would like to thank Dr. Mahmoud Gohari for statistical analysis. Funding: The study was funded by the Research Institute for Endocrine Sciences, Shahid Beheshti University of Medical Sciences.

Competing interests: None declared. 


\section{References}

1. Lobstein T, Frelut M-L. Prevalence of overweight among children in Europe. Obesity Reviews, 2003, 4:195-200.

2. Lobstein T, Baur L, Uauy R; IASO International Obesity Task Force. Obesity in children and young people: a crisis in public health. Obesity Reviews, 2004, 5(Suppl. 1):4-104.

3. Freedman DS et al. The relation of overweight to cardiovascular risk factors among children and adolescents: the Bogalusa Heart Study. Pediatrics, 1999, 103:1175-1182.

4. Serdula MK et al. Do obese children become obese adults? A review of the literature. Preventive Medicine, 1993, 22:167-177.

5. Manios $\mathrm{Y}$ et al. Cardiovascular disease risk factors among children of different socioeconomic status in Istanbul, Turkey: directions for public health and nutrition policy. Lipids in Health and Disease, 2004, 3:11-18.

6. Okosun IS et al. Trends in abdominal obesity in young people: United States 1988-2002. Ethnicity \& Disease, 2006, 16:338-344.

7. Din-Dzietham $\mathrm{R}$ et al. High blood pressure in children and adolescents in national surveys, 1963 to 2002. Circulation, 2007, 116:1437-1439.

8. McCarthy HD. Body fat measurements in children as predictors for the metabolic syndrome: focus on waist circumference. Proceedings of the Nutrition Society, 2006, 65:385-392.

9. Kelishadi $\mathrm{R}$ et al. Obesity and associated modifiable environmental factors in Iranian adolescents: Isfahan Healthy Heart Program - Heart Health Promotion from Childhood. Pediatrics International, 2003, 45:435-442.

10. Maddah M. Overweight and obesity among Iranian female adolescents in Rasht: more overweight in the lower social group. Public Health Nutrition, 2006, 10:450-453.

11. Hamidi A et al. Obesity and associated cardiovascular risk factors in Iranian children: a cross-sectional study. Pediatrics International, 2006, 48:566-571.

12. Esmaillzadeh A et al. High prevalence of the metabolic syndrome in Iranian adolescents. Obesity (Silver Spring, Md.), 2006, 14:377-382.

13. Azizi $\mathrm{F}$ et al. Tehran Lipid and Glucose Study: rationale and design. CVD prevention, 2000, 3:242-247.

14. Friedewald WT, Levy RI, Fredrickson DS. Estimation of the concentration of low-density lipoprotein cholesterol in plasma, without use of the preparative ultracentrifuge. Clinical Chemistry, 1972, 18:499-502.

15. Cole TJ et al. Establishing a standard definition for child overweight and obesity worldwide: international survey. $B M$ (Clinical Research Ed.), 2000, 320:1240-1243.

16. Franklin FA Jr, Dashti N, Franklin CC. Evaluation and management of dyslipoproteinemia in children. Endocrinology and Metabolism Clinics of North America, 1998, 27:641-654.

17. Kozan $\mathrm{O}$ et al. Prevalence of the metabolic syndrome among Turkish adults. European Journal of Clinical Nutrition, 2007, 61:548-553.

18. Al-Shafaee MA et al. Prevalence of metabolic syndrome among prediabetic Omani adults: a preliminary study. Metabolic Syndrome and Related Disorders, 2008, 6:275-279.

19. Kelishadi $\mathrm{R}$ et al. Dietary fat intake and lipid profiles of Iranian adolescents: Isfahan Healthy Heart Program? Heart Health Promotion from Childhood. Preventive Medicine, 2004, 39:760-766

20. Ogden $\mathrm{CL}$ et al. Prevalence and trends in overweight among US children and adolescents, 1999-2000. Journal of the American Medical Association, 2002, 288:1728-1732.

21. Hedley AA et al. Prevalence of overweight and obesity among US children, adolescents, and adults, 1999-2002. Journal of the American Medical Association, 2004, 291:2847-2850.

22. Thompson DR et al. Childhood overweight and cardiovascular disease risk factors: the National Heart, Lung, and Blood Institute Growth and Health Study. Journal of Pediatrics, 2007 , 150:18-25.

23. Kim HM et al. Obesity and cardiovascular risk factors in Korean children and adolescents aged 10-18 years from the Korean National Health and Nutrition Examination Survey, 1998 and 2001. American Journal of Epidemiology, 2006, 164:787-793

24. Ford ES, Mokdad AH, Ajani UA. Trends in risk factors for cardiovascular disease among children and adolescents in the United States. Pediatrics, 2004, 114:1534-1544.

25. Maffeis $\mathrm{C}$ et al. Waist circumference and cardiovascular risk factors in prepubertal children. Obesity Research, 2001, 9:179-187. 